\title{
Relatively High Seroprevalence of Hepatitis B Surface Antigen in Female Civil Servants in Enugu State of Nigeria
}

\author{
Sylvester Chuks Nwokediuko, Uchenna ljoma \\ Gastroenterology Unit, Department of Medicine, University of Nigeria Teaching Hospital \\ Enugu State, Nigeria
}

Correspondence: Sylvester Chuks Nwokediuko, Gastroenterology Unit, Department of Medicine, University of Nigeria Teaching Hospital, Ituku/Ozalla, PMB 01129 Enugu, Enugu State, Nigeria, Phone:2348033218181, e-mail: Sylvester.nwokediuko@unn.edu.ng

\section{ABSTRACT}

Background/Objective: Hepatitis B virus (HBV) infection has remained a global public health challenge. Nigeria is in the high endemicity group with a prevalence of $8 \%$ or higher. The authors seized the opportunity of the 2010 . World Hepatitis Day to mount a public enlightenment campaign and also screen civil servant in Enugu State of Nigeria for the infection.

Materials and methods: In this cross-sectional study, civil servants attached to Government House, Enugu, Nigeria, were administered a structured questionnaire containing the putative risk factors for HBV transmission. They also underwent screening for hepatitis B surface antigen (HBsAg) in blood.

Results: Out of 395 civil servants (206 males and 189 females) who participated in the screening, 36 were position for HBsAg giving a seroprevalence of $7.6 \%$. Majority of the seropostive subjects $(86.7 \%)$ were females $(p<0.001)$.

Among the risk factors examined, past history of native uvulectomy, sharing of toothbrush, sharing of razor blades and hair clippers were significantly more prevalent in the HBsAg positive group compared to the HBsAg negative subjects.

In the females who had circumcision, the HBsAg seroprevalence was significantly higher than in the uncircumcized group ( $p=0.014$, odds ratio $=3.13)$.

Conclusion: The seroprevalence of HBsAg in civil servants of Enugu State of Nigeria was 7.6\%. More females than males were $\mathrm{HBsAg}$ seropositive and this may be related to previous circumcision in the females.

Abbreviations: HBV—Hepatitis B virus; Apo—Apolipoprotein; Tg—Transgenic; HBsAg—Hepatitis B surface antigen; HCV—Hepatitis C virus; WHO-World Health Organization.

Keywords: HBsAg, Female Nigerians, Circumcision.

\section{INTRODUCTION}

Approximately one-third of the world's population has serological evidence of past or present infection by hepatitis $\mathrm{B}$ virus (HBV) and 350 million people are chronically infected. ${ }^{1,2}$ The natural history of HBV infection and spectrum of liver disease it causes are diverse and variable, ranging from a low viremic inactive carrier state to a progressive chronic hepatitis, which may evolve to cirrhosis and hepatocellular carcinoma. ${ }^{3}$

Clinical observations and death statistics support the view that chronic hepatitis $\mathrm{B}$ appears to progress more rapidly in males than females..$^{4-7}$ One of the reasons that has been proposed for this observation is the production of more vigorous cellular and humoral immune reactions by females compared to males. ${ }^{8,9}$ In the same vein, male sex is one of the predictors associated with a non-response to HBV vaccination. ${ }^{10}$ These and other studies ${ }^{11,12}$ hinge the explanation on sex hormones; there is a favorable role of estrogen in HBV-related chronic liver diseases ${ }^{13}$ More recently, Chinese researchers came up with a landmark discovery to explain the long-standing mystery of why hepatitis B virus sexually discriminates, hitting men harder than women. In that study, they showed that apolipoprotein A1 (Apo A1) expression is down-regulated in male and female HBV transgenic (HBV-Tg) mouse liver, and that there is disordered expression pattern of Apo A1 isoforms in male HBV-Tg mouse liver. This finding was also verified in chronic hepatitis B patient serum. ${ }^{14}$

In this seroprevalence study, the authors seized the opportunity of 2010 World Hepatitis Day to mount a public enlightenment campaign and screening of civil servants of Enugu State of Nigeria, for HBV infection using the surrogate marker, hepatitis B surface antigen (HBsAg). Selected risk factors for HBV transmission were also determined. 


\section{MATERIALS AND METHODS}

This was a cross-sectional seroprevalence study in which civil servants attached to Government House, Enugu, constituted the study population. Informed consent was obtained from all the participants and a structured questionnaire containing the putative risk factors for HBV infection was administered to them. Venous blood was obtained and tested for HBsAg using a 3rd generation enzyme immunoassay (Cobas Core HBsAg EIA) manufactured by M/S Roche Diagnostics GmbH Werk Penzberg, Germany. This kit uses polystyrene microwell strips precoated with monoclonal antibodies specific to HBsAg. The results were analyzed using the computer software SPSS version 15 and expressed as means and proportions. Differences between means and proportions were determined by using student's t-test and $\chi^{2}$. A p-value of $<0.05$ was considered significant. Strength of association was determined using relative risk and odds ratio.

\section{RESULTS}

A total of 395 civil servants participated in the study. This was made up of 206 males (52.2\%) and 189 females (47.8\%). Thirty-six civil servants were positive for HBsAg, giving a seroprevalence of $7.6 \%$. Out of this number, four were males (13.3\%) and 26 were females (86.7\%). The difference between the seroprevalence in males and females was statistically significant $(\mathrm{p}<0.001)$. Around 395 civil servants who participated in the study were made up of 172 senior staff (43.5\%) and 223 junior staff (56.5\%). Among the senior staff, four were HBsAg positive (3.5\%) while 24 junior workers were HBsAg positive (10.8\%). The difference between the two prevalences was statistically significant $(\mathrm{p}=0.0117)$. Table 1 illustrates the HBsAg serostatus of the civil servants. The ages of the civil servants ranged between 19 and 77 years (mean $=43.65 \pm 10.77$ years). The ages of the males ranged between 19 and 66 years (mean $=46.18 \pm 10.42$ years). The age of the females ranged between 20 and 70 years (mean $=40.67 \pm 10.21$ years). The difference between the two means was not statistically significant $(p=0.9142)$.

\begin{tabular}{|c|c|c|c|}
\hline Group & $\begin{array}{l}\text { HBsAg } \\
\text { positive }\end{array}$ & $\begin{array}{l}\text { HBsAg } \\
\text { negative }\end{array}$ & Total \\
\hline Junior workers & 24 (10.8\%) & 199 (89.2\%) & 223 (100\%) \\
\hline Senior workers & $6(3.5 \%)$ & 166 (96.5\%) & 172 (100\%) \\
\hline Total & 30 (7.6\%) & 365 (92.4\%) & 395 (100\%) \\
\hline
\end{tabular}

The mean age of the HBsAg positive subjects was $43.0 \pm 9.91$ years while the mean age of the HBsAg negative subjects was $43.7 \pm 10.87$. The difference between the two means was not statistically significant $(\mathrm{p}=0.9748)$. The risk factors for HBV infection were determined in the subjects. Past history of native uvulectomy, sharing of toothbrush and sharing of razor blades/hair clippers were significantly more prevalent in the HBsAg positive subjects compared to the HBsAg negative subjects ( $\mathrm{p}=0.0297,0.0297$ and 0.0077 respectively). Table 2 illustrates the risk factors.

Out of the 189 female civil servants who participated in the study, 65 gave a history of having undergone circumcision (34.4\%). Sixteen of them were HBsAg positive (24.6\%) while 49 (75.4\%) were HBsAg negative. Eightynine had no circumcision (47.1\%). Seven of them (7.9\%) were HBsAg positive while 82 (92.1\%) were HBsAg negative. Thirty-five females (18.5\%) were not sure if they were circumcised or not (Table 3). The difference between the HBsAg seroprevalence in the circumcised group and HBsAg seroprevalence in the uncircumcised group was statistically significant $(\mathrm{p}=0.014$, relative risk $=0.4593$, odds ratio $=3.13)$.

\section{DISCUSSION}

The medical literature is replete with studies on the seroprevalence of HBsAg in different cohorts in Nigeria. ${ }^{15-20}$ Most of the studies were carried out on blood donors, pregnant women or hospital patients. In this study, apparently healthy civil servants were used and the seroprevalence was $7.6 \%$. This figure is above the upper limit for regions with intermediate prevalence (2-7\%).

Among the risk factors studied, only native uvulectomy performed for sore throat, sharing of toothbrush and sharing of razor blades/clippers were significantly more prevalent among those who tested positive for HBsAg compared to those who were seronegative. This suggests that there is a significant contribution to disease burden by those unhealthy practices. The chance of transmitting infection through sharing of sharp body piercing objects and toothbrush is likely to be substantial considering the fact that such practices are likely to have occurred over prolonged periods.

Uvulectomy is practiced in most African communities, including Nigeria. It is usually carried out by local practitioners in less than optimal hygienic conditions. Apart from the risk of transmitting infections, like HBV, hepatitis $\mathrm{C}$ virus (HCV) and human immunodeficiency virus (HIV), it carries other risks, like bleeding, anemia, sepsis, tetanus and death. ${ }^{21}$

The seroprevalence of HBsAg in this study was significantly higher among the junior staff compared to the 
Table 2: Risk factors for HBV infection in HBsAg seropositive and HBsAg seronegative subjects

\begin{tabular}{|c|c|c|c|c|c|c|}
\hline Risk factor & $\begin{array}{c}\text { HBsAg } \\
\text { positive (\%) }\end{array}$ & $\begin{array}{c}\text { HBsAg } \\
\text { negative(\%) }\end{array}$ & $\chi^{2}$ & p-value & Relative risk & Odds ratio \\
\hline Jaundice & 10 & 6.2 & 0.5684 & 0.4509 & 1.544 & 1.618 \\
\hline Transfusion & 6.7 & 9.8 & 0.2626 & 0.6083 & 0.6991 & 0.6819 \\
\hline Injection from quacks & 29.6 & 18.8 & 1.1720 & 0.2791 & 1.514 & 1.579 \\
\hline Scarification & 13.3 & 20.0 & 0.5549 & 0.4563 & 0.6842 & 0.6667 \\
\hline Family history of liver disease & 0 & 1.015 & 1.0150 & 0.3137 & 0.0000 & 0.4644 \\
\hline Multiple sex partner & 22.2 & 19.0 & 0.1145 & 0.7351 & 1.158 & 1.173 \\
\hline Occupational exposure & 0 & 2.9 & 0.7878 & 0.3748 & 0.0000 & 0.5931 \\
\hline Toothbrush & 28.0 & 10.6 & 4.7260 & $0.0297 *$ & 2.373 & 2.648 \\
\hline Razor/Clipper & 38.5 & 13.6 & 7.1090 & $0.0077 *$ & 2.500 & 2.826 \\
\hline Surgery & 37.0 & 36.7 & 0.000548 & 0.9813 & 1.008 & 1.009 \\
\hline Uvulectomy & 28.0 & 10.6 & 4.7260 & $0.0297 *$ & 2.373 & 2.648 \\
\hline
\end{tabular}

*Statistically significant

\begin{tabular}{|c|c|c|c|}
\hline $\begin{array}{l}\text { Circumcision } \\
\text { status }\end{array}$ & $\begin{array}{l}\text { HBsAg } \\
\text { positive }\end{array}$ & $\begin{array}{l}\text { HBsAg } \\
\text { negative }\end{array}$ & Total \\
\hline Circumcised & $16(24.6 \%)$ & 49 (75.4\%) & 65 (100\%) \\
\hline Not circumcised & 7 (7.9\%) & 82 (92.1\%) & 89 (100\%) \\
\hline Not sure & $3(8.6 \%)$ & 32 (91.4\%) & 35 (100\%) \\
\hline Total & 26 (13.8\%) & 163 (86.2\%) & 189 (100\%) \\
\hline
\end{tabular}

senior staff ( $p=0.0117)$. This is not surprising because most of the unhealthy practices and behaviors that constitute the risk factors for the spread of HBV are likely to be more prevalent in people in the lower socioeconomic cadre of the society. If more efforts are directed at public enlightenment and health education, this trend can be checked.

In this study, the gender-specific seroprevalence of HBsAg was significantly higher in females than males. All over the world, including Nigeria, most studies have reported a greater tendency for HBV progression in males than females. ${ }^{4-14}$ The higher seroprevalence in females demonstrated in this study may be explained by the circumcision history of most of the HBsAg positive females. Even though only $34.4 \%$ of the females had a history of circumcision, 16 of them (24.6\%) were HBsAg seropositive. The difference between the HBsAg seroprevalence in the circumcised group and the seroprevalence in the uncircumcised group was statistically significant $(p=0.014)$.

Female circumcision has remained a public health concern in Nigeria. According to information from the Federal Ministry of Health, Abuja, ${ }^{15,22}$ the practice is widespread covering practically every state of the federation though in varying magnitude from infancy to childhood.
The prevalence is highest in the South-West and SouthEast and lowest in the North-West and North-East. Though there is no legislation in Nigeria against female circumcision, the World Health Organization (WHO) has continually and unequivocally advised that female circumcision must not be institutionalized, nor should any health professional in any setting, including hospitals or in the home setting. This is why in places where it is done, it is an illicit act, carried out in very unhygienic settings with all the attendant risks. Female circumcision is fundamentally different from male circumcision. The latter is more culturally and socially accepted and, therefore, is often done in hospitals where standards of hygiene are usually ensured.

The eventual outcome of the HBV infection in those females who tested positive for HBsAg in this study will require a follow-up which is beyond the scope of this study.

In conclusion, this study has demonstrated a seroprevalence of $7.6 \%$ for HBsAg in civil servants of Enugu State of Nigeria, with a higher seroprevalence in females compared to males. The female preponderance may be related to previous female circumcision.

\section{REFERENCES}

1. EASL International Consensus Conference on Hepatitis B. Consensus statement. J Hepatol 2003;39:S3-25.

2. Fattovich G. Natural history and prognosis of hepatitis B. Semin Liver Dis 2003;23:47-58.

3. Pan CQ, Zhang JX. Natural history and clinical consequences of Hepatitis B virus infection. Int J Med Sci 2005;2:36-40.

4. McMahon BJ, Alberts SR, Wainwright RB, Bulkow L, Lanier AP. Hepatitis B-related sequelae. Prospective study in 1400 hepatitis B surface antigen positive Alaska native carriers. Ach Intern Med 1990;150:1051-54.

5. Award WL, McMahon BJ, Hall DB, Heyward WL, Francis DP, Bender TR. The long-term serological course of asymptomatic hepatitis $\mathrm{B}$ virus carriers and the development of primary hepatocellular carcinoma. J Infect Dis 1985;151:604-09. 
6. Yuen MF, Tanaka Y, Fong DY, Fung J, Wong DK, Yuer JC, But DY, Chan AO, Wong BC, Mizokami M, Lai CI. Independent risk factors and predictive score for the development of hepatocellular carcinoma in chronic hepatitis B. J Hepatol 2008; 50(1):7-9.

7. Zacharakis GH, Koskinas J, Kotsiou S, Papoutselis M, Tzara F, Vafeiadis N, Archimandritis AJ, Papoutselis K. Natural history of chronic hepatitis B virus infection: A cohort study with up to 12 years follow-up in North Greece (part of the Interreg I-II/EC project). J Med Virol 2005;77:173-79.

8. Ansar AS, Penhale WJ, Talal N. Sex hormones, immune responses and autoimmune diseases. Mechanism of sex hormone action. Am J Pathol 1985;121:531-51.

9. Grossman CJ. Interactions between gonadal steroids and the immune system. Science 1985;227:257-61.

10. Sjogren $\mathrm{MH}$. Prevention of hepatitis B in non-responders to initial hepatitis B virus vaccination. Am J Med 2005;118 (Suppl 10A):S34-39.

11. Fox HS, Bond BL, Parslow TG. Estrogen regulates the INFgamma promoter. J Immunol 1991;146:4362-67.

12. Clerini E, Bergamasco E, Ferrario E, Villa ML. Influence of sex steroids on the antigen-specific primary antibody response in vitro. J Clin Lab Immunol 1991;34:71-78.

13. Shimizu I, Kohno N, Tamaki K, Shono M, Huang HW, He JH, Yao DF. Female hepatology: Favorable role of estrogen in chronic liver disease with hepatitis B virus infection. World J Gastroenterol 2007;13(32):4295-305.

14. Yang FU, Yin Y, Wang F, Zhang L, Wang Y, Shun S. An altered pattern of liver apolipoprotein A-1 isoforms is implicated in male chronic hepatitis B progression. Journal of Proteome Research 2010;9:134-43.

15. Obi SN, Onah HE, Ezugwu FO. Risk factors for hepatitis B infection during pregnancy in a Nigerian obstetric population. Journal of Obstetrics and Gynaecology 2006;26(8):770-72.

16. Umolu PI, Okoror LE, Orhue P. Human immunodeficiency virus (HIV) seropositivity and hepatitis B surface antigenemia (HBsAg) among blood donors in Benin city, Edo State, Nigeria. African Health Sciences 2005;5(1):55-58.

17. Bada AS, Olatunji PO, Adewuyi JO, Iseniyi JO, Onile BA. Hepatitis B surface antigenemia in Ilorin, Kwara State, Nigeria. Cent Afr J Med 1996;42(5):139-41.

18. Sirisena ND, Njoku MO, Idoko JA, Isamade E, Barau C, Jelpe D, Zamzni A, Otowo S. Carriage rate of hepatitis B surface antigen (HBsAg) in an urban community in Jos, Plateau State, Nigeria. Niger Postgrad Med J 2002;9(1):7-10.

19. Pennap GR, Yakubu A, Oyige O, Forbi J. Prevalence of hepatitis $\mathrm{B}$ and $\mathrm{C}$ virus infection among people of a local community in Keffi, Nigeria. African Journal of Microbiology Research 2010;4(4):274-78.

20. Buseri FI, Muhibi MA, Jeremiah ZA. Sero-epidemiology of transfusion-transmissible infectious diseases among blood donors in Osogbo, South-West Nigeria. Blood Transfusion 2009;7(4):293-99.

21. Olaosun AO, Ojemakinde KO, Raji AA, Adedeji TO, Adebola SO. Death of child with leukemia subjected to uvulectomy. The Internet Journal of Third World Medicine 2007;4(2).

22. Family Health Department, Federal Ministry of Health Abuja/ WHO Central District Abuja. Elimination of female genital circumcision in Nigeria December 2007. 